(i)

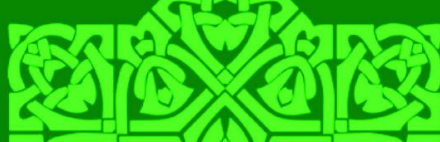
tह

Muhammad Yusuf, Baharuddin, Mardan The Quranic Hermeneutics Approach to Gender Equality in Amina Wadud Muhsin's View

A. Zamakhsyari Baharuddin التظاهر بالشعار ات القومية في شعيرة الحج و العمرة

Andi Muhammad Ridwan, Baso Pallawagau Falsafah Al-Wujudiyyah Al-Sufiyyah: Asluha Al-Dini wa Manqif Al-Ulama Minha

Muhammad Widus Sempo, Norita Binti Md Norwawi, Hasyim Haddade, Yousuf Mahbubul Islam, Noorhayati Binti Hasyim Unbelievers' Mental Model and Behavioural Disorders Based on Their Queries in The Al-Baqarah Chapter

Sri Sunantri, Achmad Abubakar, Kamaluddin Abu Nawas, Firdaus Methodology of Interpretation of Muhammad Amin Al-Syinqiti

Amirullah, Andi Achruh AB. Pasinringi, Rahmawansyah Sahib The Transformation of The Muamalah Fiqh Akad at Saga Abepura-Papua Mall During The Covid 19 Pandemic

Irwan Misbach Siri'Na Pacce Culture in Retailer Based on Islamic Perspective Business Ethics

Abd. Rahman R Family Resilience in Islamic Perspective (A Case Study of Parent and Child Interaction Behavior in The District of Somba Opu Gowa)

Vol. 20 No. $2 / 2020$ 


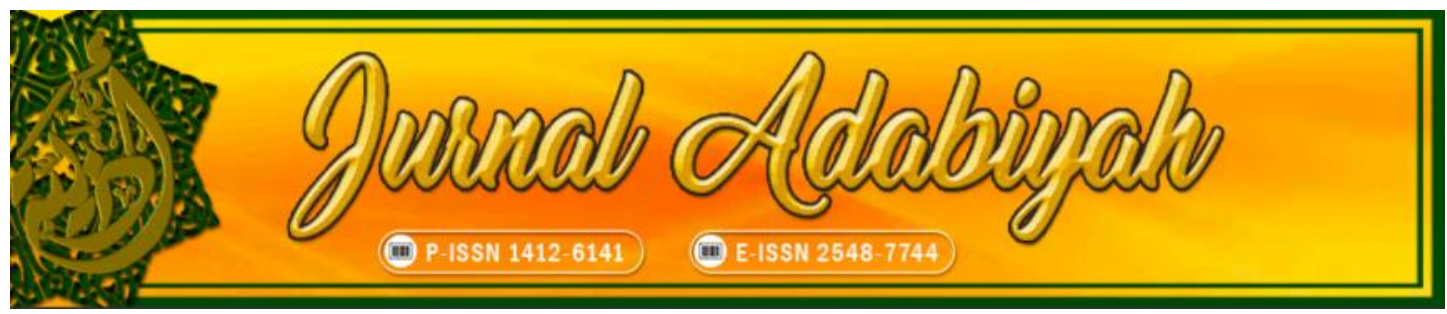

Theme: Islamic Studies

VOLUME 20 NO. 2 DECEMBER 2020

\section{EDITOR-IN-CHIEF}

Barsihannor, Alauddin State Islamic University, Indonesia

\section{INTERNATIONAL EDITORIAL BOARD}

Nuri Emmiyati, Alauddin State Islamic University, Indonesia

Minako Sakai, Australian National University (ANU), Australia

Abd Rauf Muhammad Amin, Fakulti Syariah Kupu SB Brunei Darussalam, Brunei Darussalam

Muhammad Widus Sempo, Universiti Sains Islam Malaysia, Malaysia

Salih Yousif Sharaf Mohamed, Al-Gazera University, Sudan

Aishah Waenaha Waemamah, Academy of Islamic and Arabic Studies Princess of Naradhiwas University - Thailand, Thailand

\section{EXECUTIVE EDITOR}

Umar Thamrin, Alauddin State Islamic University, Indonesia

\section{MANAGING EDITOR}

Nasrum, Alauddin State Islamic University, Indonesia

\section{EDITORS}

Rosmah Tami, Alauddin State Islamic University, Indonesia Haniah Haniah, Alauddin State Islamic University, Indonesia Zaenal Abidin, Alauddin State Islamic University, Indonesia

Awaluddin Syamsu, Universitas Muslim Indonesia

Ahmadi Usman, UIN Syarif Hidayatullah Jakarta, Indonesia

Baso Pallawagau, Alauddin State Islamic University, Indonesia

Muhammad Azwar, UIN Syarif Hidayatullah Jakarta, Indonesia

Muh. Saleh Syamsuri, Alauddin State Islamic University, Indonesia

Andi Satrianingsih, Muhammadiyah University, Indonesia

Syahruni - Junaid, Alauddin State Islamic University, Indonesia

Rabiatul Adawiah, Majene Islamic State College, West Sulawesi, Indonesia, Indonesia

Chusnul Chatimah Asmad, Alauddin State Islamic University, Indonesia

Nur Arifin, Alauddin State Islamic University, Indonesia

\section{IT SUPPORT}

Taufiq Mathar, Alauddin State Islamic University, Indonesia

\section{LANGUAGE ADVISOR}

Kustiwan Syarief, UIN Syarif Hidayatullah Jakarta, Indonesia Muh. Saleh Syamsuri, Alauddin State Islamic University, Indonesia

\section{COVER DESIGNER}

Nur Arifin 


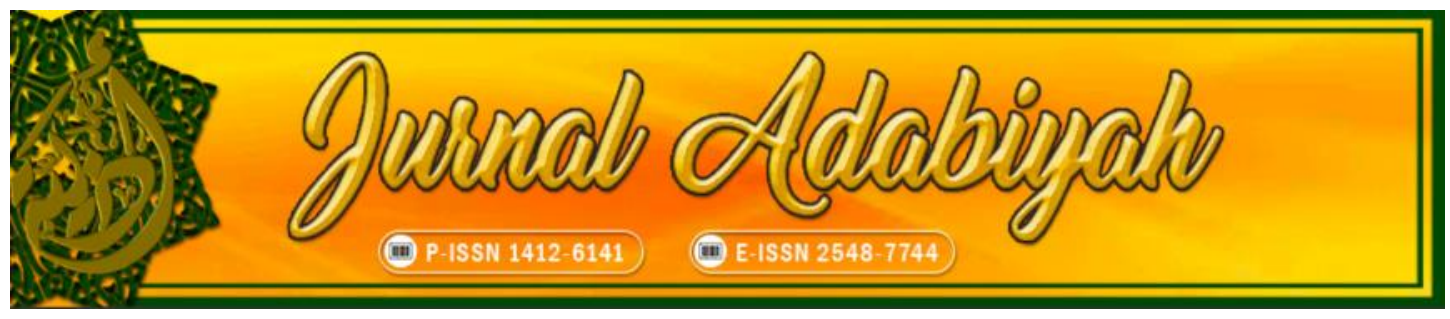

\section{Jurnal Adabiyah:}

This journal receives a national accreditation from Ministry of Research, Technology, and Higher Education Republic of Indonesia, Nomor 10/E/KPT/2019 on April 4, 2019 with the SINTA score: S2.

The Journal has been published by the Faculty of Adab and Humanity of Alauddin State Islamic University, Makassar, since 1997 and has been online since 2016 with the main themes on Humanities and Islamic Studies with the emphasis on interdisciplinary and intertextuality approach.

This journal are published twice a year, on June and December. The themes related to Islamic Studies are textual studies, scriptural traditions, Islamic law, and theology; and those related to Humanities are language, literature, history, and culture.

The journal of Humanities and Islamic Studies will provide the online collection of articles from 1997 up to now. The most updated information can be found on the website. 


\section{Table of Contents}

Muhammad Yusuf, Baharuddin, Mardan

214-237

The Quranic Hermeneutics Approach to Gender Equality in Amina Wadud Muhsin's View

A. Zamakhsyari Baharuddin

التظاهربالشعارات القومية في شعيرة الحج والعمبرة

261-285

Andi Muhammad Ridwan, Baso Pallawagau

Falsafah Al-Wujudiyyah Al-Sufiyyah: Asluha Al-Dini wa Mauqif AlUlama Minha

Muhammad Widus Sempo, Norita Binti Md Norwawi, Hasyim Haddade, Yousuf Mahbubul Islam, Noorhayati Binti Hasyim ................... 286-299 Queries in The Al-Baqarah Chapter

Sri Sunantri, Achmad Abubakar, Kamaluddin Abu Nawas, Firdaus. 300-319 Methodology of Interpretation of Muhammad Amīn Al-Syinqiti

Amirullah, Andi Achruh AB. Pasinringi, Rahmawansyah Sahib

The Transformation of The Muamalah Fiqh Akad at Saga Abepura-Papua Mall During The Covid 19 Pandemic

Irwan Misbach

Siri' Na Pacce Culture in Retailer Based on Islamic Perspective Business Ethics

Abd Rahman R

Family Resilience in Islamic Perspective (A Case Study of Parent and Child Interaction Behavior in The District of Somba Opu Gowa) 


\title{
FAMILY RESILIENCE IN ISLAMIC PERSPECTIVE (A CASE STUDY OF PARENT AND CHILD INTERACTION BEHAVIOR IN THE DISTRICT OF SOMBA OPU GOWA)
}

\author{
Abd Rahman R \\ Alauddin State Islamic University of Makassar \\ Email: abdul.rahman@uin-alauddin.ac.id
}

\begin{abstract}
This paper discusses the interaction behavior of parents and children, facing problems in carrying out the duties and roles of the child's parents as the person in charge and the first teacher of understanding and practicing children's religiosity. This paper aims to find and describe the interaction patterns of children's parents, constraints and challenges in carrying out their duties as the first teacher in the family and effective efforts to foster children in the family. This paper is qualitative descriptive, with deductive-inductive methods. Data relying on primary sources through observation and interviews, and is complemented by secondary data obtained from literature. This paper shows the relationship between interaction behavior, the position of father and mother and child with family resilience through internalization of religious norms and values, understanding and practicing the teachings of the faith, praying five times a day, and noble morals. Parent and child interactions are temporal in nature, depending on the conditions of parents and children in the process of interaction in the family. The routine and personality activities of parents who are competent in understanding Islam are relatively constraints and challenges in the interaction between parents and children in carrying out their functions, the role of being the first teacher in the family. This paper is an indicator and motivator that encourage family life to foster children in understanding and practicing the principles of Islam. Keywords: Family resilience, behavior, interaction, parents of children, Islam.
\end{abstract}

Keywords: Family Resilience; Behavior; Interaction; Parents; Children; Islam.

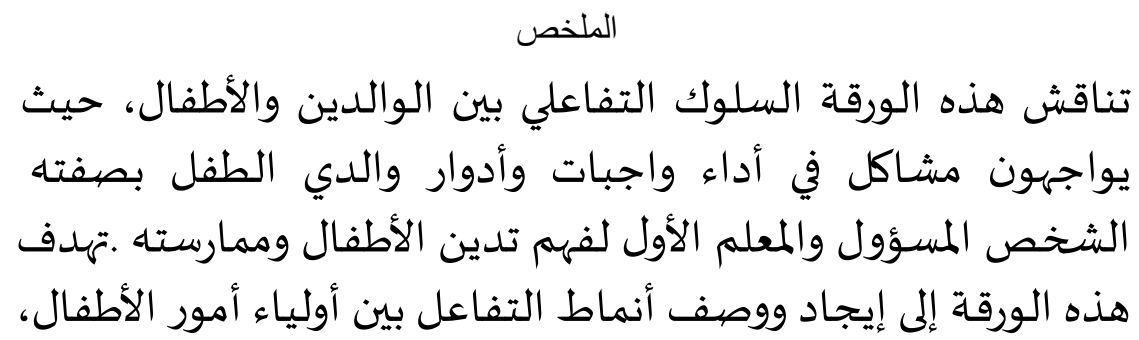


Family Resilience in Islamic Perspective

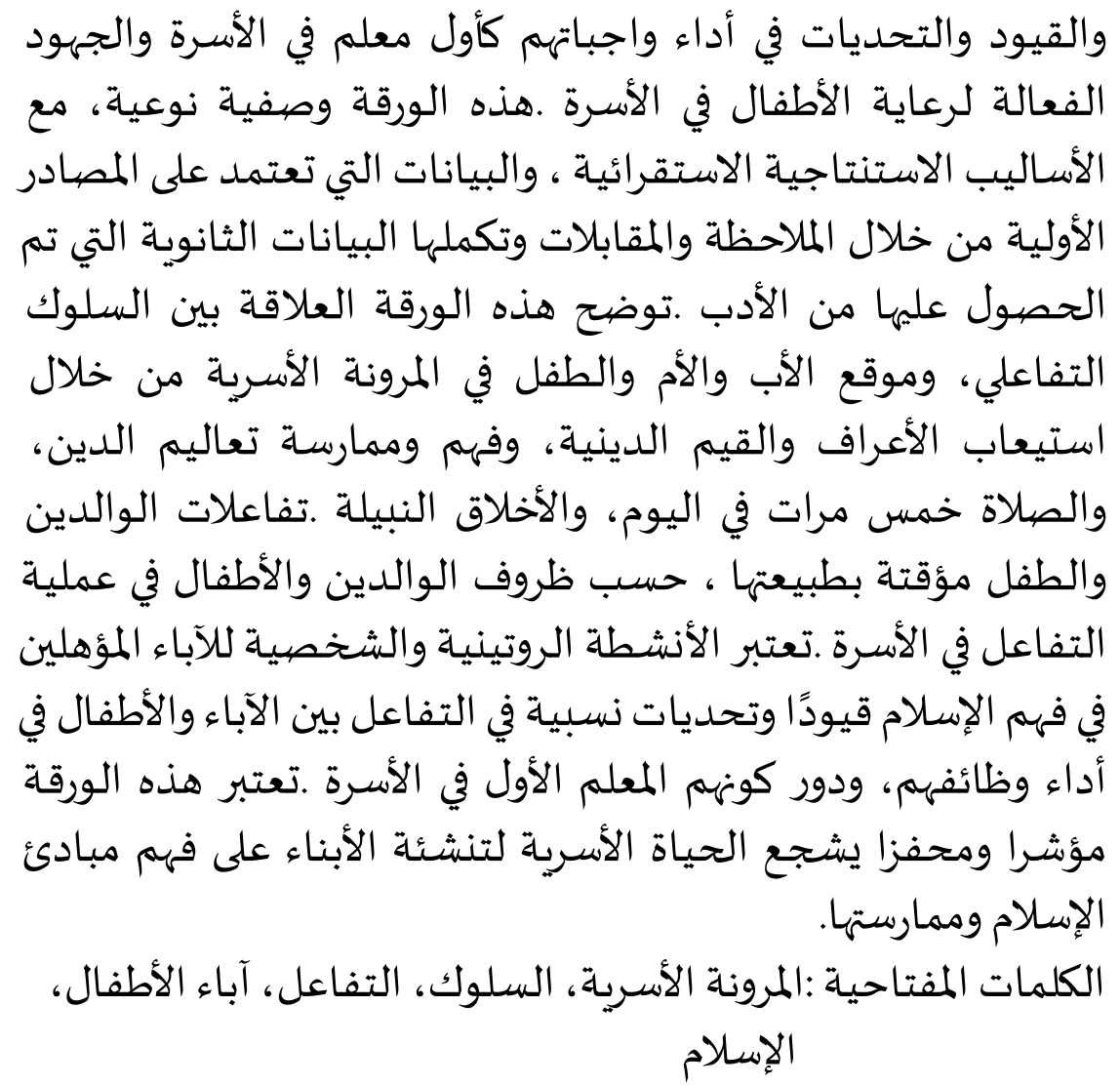

\begin{abstract}
Abstrak
Tulisan ini membahas tentang perilaku interaksi orang tua dan anak, menghadapi problema dalam menjalankan tugas dan peran orang tua anak sebagai penanggung jawab dan guru pertama terhadap pemahaman dan pengamalan relegiutas anak. Tulisan ini bertujuan untuk menemukan dan mendeskripsikan pola interaksi orang tua anak, kendala dan tantangan dalam mengemban tugasnya sebagai guru pertama dalam keluarga serta upaya yang efektif pembinaan anak-anak dalam keluarga. Tulisan ini bersifat deskriftif kualitatif, dengan metode deduktif-induktif, data disandarkan kepada sumber primer melalui observasi, wawancara dan dilengkapi oleh data sekunder yang diperoleh dari leteratur. Tulisan ini menunjukkan kaitan perilaku interaksi, posisi ayah dan ibu serta anak dengan ketahanan keluarga melalui internalisasi norma dan nilai agama, pemahaman dan pengamalan ajaran akidah, salat lima waktu, serta akhlak mulia. Interaksi orang tua dan anak bersifat temporal, tergantung pada kondisi orang tua dan anak dalam proses interaksi dalam keluarga. Kesibukan rutinitas dan kepribadian` orang tua yang bersifat kompetensi pemahaman terhadap Islam relative menjadi faktor kendala dan tantangan dalam interaksi orang tua dan anak dalam menjalankan fungsi,
\end{abstract}


peran sebagai guru pertama dalam keluarga. Tulisan ini menjadi indikator dan motivator yang mendorong kehidupan keluarga untuk pembinaan anak-anak dalam pemahaman dan pengamalan ajaran-ajaran prinsip dalam Islam.

\section{Kata Kunci: Ketahanan Keluarga; Perilaku; Interaksi; Orang Tua Anak; Islam}

\section{A. Introduction}

The family as the smallest institution in a society, which consists of children on the one hand as members of the family in the household, needs guidance so that it grows and develops into the nation's hopeful child, ${ }^{1}$ it turns out that facing household problems in the behavior of parent-child interaction is a part of the globalization of interactions that influence each other with various personal, and family interests, including religious, economic and social interests. ${ }^{2}$ William Stern, as quoted by Abu Ahmad Ahmadi in the Convergence theory, said that the development of a child is influenced by the nature and the surrounding environment. ${ }^{3}$ It is on this side that the parents as educators, the first teachers for their children, as well as the responsibility for the household. ${ }^{4}$ Family life, parents and children, time to gather with family or to introduce the norms of praiseworthy values eroded by a lifestyle with all the amenities, TV broadcasts with various broadcasts that take up a lot of children's time to sit in front of the TV and their busy lives, experiencing the same thing, plus busy office work, business so that the house as a strategic place for family members to interact, ${ }^{5}$ ccollaborate, for all family members get less attention. The pattern and time of interaction between parents and children are reduced, both in quantity and quality, thus affecting the development and formation of children's character. ${ }^{6}$ Parents become determinants, give colors according to the method and intensity of interaction in caring for, and educate their children in the family to avoid domestic commotion that affects the life of the wider society.

${ }^{1}$ Afiful Ikhwan, Oktio Frenki Biantoro, and Ali Rohmad, 'The Role of the Family in Internalizing Islamic Values', Dinamika Ilmu, 19.2 (2019), p. 325.

${ }^{2}$ Suratno, 'Pengaruh Lingkungan Keluarga Dan Lingkungan Pergaulan Terhadap Prestasi Belajar Ekonomi Siswa', Pengaruh Lingkungan Keluarga Dan Lingkungan Pergaulan Terhadap Prestasi Belajar Ekonomi Siswa, 9.1 (2014), p. 93.

${ }^{3}$ Abu Ahmadi, Psikologi Sosial (T.tp: Riska Cipta, t.t.), p. 56.

${ }^{4}$ Ach. Puniman and Kadarisman Kadarisman, 'Pendidikan Anak dalam Perspektif Islam', Alpen: Jurnal Pendidikan Dasar, (2018), p. 2.

${ }^{5}$ M. Hidayat Ginanjar, 'Keseimbangan Peran Orang Tua dalam Pembentukan Karakter Anak', Edukasi Islami: Jurnal Pendidikan Islam, 2.03 (2017) , p. 230.

${ }^{6}$ Suratno, h. 94. 
Family Resilience in Islamic Perspective

(A Case Study of Parent and Child Interaction

Abd Rahman $R$

Behavior in The District of Somba Opu Gowa)

So far the study of family resilience has emphasized the aspects of coping through social psychological resilience. Rondang Siahaan and Ismail see family resilience from an economic aspect. ${ }^{8}$ Herlina sees family resilience through gender harmony. ${ }^{9}$ Research on the interaction behavior of parents and children places more emphasis on aspects of verbal violence, the factors that cause violence against children. ${ }^{10}$ Novrinda et al, emphasize more on the role of parents from the aspect of background education. Mahmudi et al in their writings emphasize the urgency of moral education as a concept, still ignoring the aspects of its application in domestic life. ${ }^{11}$ In the case of households as the first environment for family members to interact between parents and children based on family resilience, through the cultivation of faith and the formation of morals. ${ }^{12}$ The interaction behavior of parents and children based on family resilience needs to be seen from the principles of Islamic teachings, namely faith, understanding and practice of the five daily prayers and noble morals. Relationships between parents and children, as well as the rights and obligations of parents to their children in caring for, maintaining and fulfilling their physical and mental, physical and spiritual needs through interaction in an Islamicbased family by instilling a faith, practicing the five daily prayers accompanied by education of noble character. This hope can be realized through a fairly long process and time pattern.

The purpose of this paper is to complement the shortcomings of existing studies that only look at family resilience from the aspect of material needs as a driving and inhibiting factor for family resilience. This paper places the interaction behavior of parents in coaching their children in the family by providing non-material guidance (faith, understanding and practice of noble norms and values) as an effort to maintain family resilience. In line with that, three questions were raised; (a) how is the behavior of the interaction of parents on fostering children in the family in Somba

${ }^{7}$ Putri Limilia and Benazir Bona Pratamawaty, 'Pelatihan Literasi Media Digital Sebagai Penanggulangan Dampak Negatif Internet Pada Ketahanan Keluarga’, Jurnal Abdi MOESTOPO, 01.01 (2017), p. 1.

${ }^{8}$ Rondang Siahaan, 'Ketahanan Sosial Keluarga: Perspektif Pekerjaan Sosial (Family Resiliency: Sosial Work Perspective)', Informasi, 17.02 (2012), p. 82. Ismail, 'Optimalisasi Pelaksanaan Program Kelompok Usaha Mandiri Masyarakat - Program Ibu Mandiri Dalam Meningkatkan Pendapatan Rumah Tangga Dan Implikasinya Terhadap Ketahanan Ekonomi Rumah Tangga (Study at PKPU Yogyakarta)', Jurnal Ketahanan Nasional, 21.3 (2015), p. 145.

${ }^{9}$ Herlina, 'Gender Harmony Dalam Pembangunan Ketahanan Keluarga', Jurnal Al-Himayah, 2.1 (2018), p. 119.

${ }^{10}$ Yuni Fitriana, Kurniasari Pratiwi, and Andina Vita Sutanto, 'Faktor-Faktor Yang Berhubungan Dengan Perilaku Orang Tua dalam Melakukan Kekerasan Verbal Terhadap Anak Usia Pra-Sekolah', Jurnal Psikologi Undip, 14.1 (2015), p. 81-93

${ }^{11}$ Mahmudi Mahmudi and others, 'Urgensi Pendidikan Akhlak dalam Pandangan Imam Ibnu Qayyim Al-Jauziyyah', Ta’dibuna: Jurnal Pendidikan Islam, 8.1 (2019), p. 17.

${ }^{12}$ Mufatihatut Taubah, 'Pendidikan Anak dalam Keluarga Perspektif Islam Mufatihatut Taubah (Lecture Stain Kudus study program of Pai)', JUrnal Pendidikan Agama Islam, 3.1 (2016), p. 109. 
Opu Gowa Subdistrict? Effective interaction in an Islam-based family can build family resilience. The three questions form the problem formulation in this paper and are described sequentially according to the sub-problems that have been raised above.

This paper is based on three assumptions. First, Islamic-based parent and child interaction behavior is practiced in family life as the obligation of parents to their children, the allocation of time to sit together is eroded by their respective busyness, second, Islamic-based parent and child interaction behavior in facing challenges and obstacles, especially competence and the personality of the parents coupled with busyness factor. The interaction behavior of parents and children is only temporary without sufficient time allocation. Third, it takes a parent and child interaction behavior that is effective, wise, and accommodative so that educated children are born, devout in conducting worship the five daily prayers, behave honorably in family life and society.

\section{B. Literature Review}

\section{Family Resilience}

Community is a group of families consisting of parents and children, who live in it, need various necessities of life, one another has duties and roles that contribute to maintaining and maintaining the integrity of family life. ${ }^{13}$ Family resilience is needed by every family in order to face various social, economic and cultural problems in society. Family resilience is a description of the ability to meet the basic needs of the family, both in religious and spiritual aspects. ${ }^{14}$ The condition of a compact, prosperous and advanced family and having a solid religious foundation, understanding and practicing good religious teachings will be able to face all temptations and attacks that have the potential to damage the family's resilience. A solid family not only faces the problems, but also can provide solutions to the problems. ${ }^{15}$ Family resilience is a characteristic, dimension and ability of a family to help families solve problems and find solutions by increasing the adaptability of family members in crisis situations. ${ }^{16}$

Family resilience through positive behavior patterns is an ability that functions personally in the family to be able to face bad conditions, pressures and difficulties. ${ }^{17}$ Non-physical endurance is the fulfillment of mental, spiritual-psychological needs, protection, peace, full of love, sakinah mawadah wa rahmah in family life. ${ }^{18}$ The

${ }^{13}$ Ike Herdiana, Dr. Suryanto, and Seger Handoyo, 'Family Resilience: A Conceptual Review', (2018), p. 42.

${ }^{14}$ Ike Herdiana, Suryanto, and Handoyo.

${ }^{15}$ Hasan Baharun, 'Pendidikan Anak dalam Keluarga; Telaah Epistemologis', Jurnal Pedidikan, 3.2 (2016), p. 97.

${ }^{16}$ Ike Herdiana, Suryanto, and Seger Handoyo.

${ }^{17}$ Siahaan.

${ }^{18}$ Rizqi Maulida Amalia, Muhammad Yudi Ali Akbar, and Syariful Syariful, 'Ketahanan Keluarga dan Kontribusinya bagi Penanggulangan Faktor Terjadinya Perceraian', Jurnal Al-Azhar Indonesia Seri Humaniora, 4.2 (2018), p. 131. 
Family Resilience in Islamic Perspective

(A Case Study of Parent and Child Interaction

Abd Rahman $R$

Behavior in The District of Somba Opu Gowa)

family needs a condition of functional relationship between parents and children in developing not only external needs, but also internal needs. ${ }^{19}$ Obedience and submission to religious norms regulating the rights and obligations of family members create family resilience Family resilience that is based and built on Islamic teachings is protective and curative, as well as optimism in facing the challenges and difficulties of a family's life. The strength of faith and worship experiences and commendable morals that are integrated in children give birth to the ability and tenacity to face difficulties as a manifestation of personal integrity as a strategy for family resilience.

\section{Interaction Behavior}

The interaction behavior of parents and children determines the direction and color of family life. ${ }^{20}$ The response or reaction of the child as a family member is stimulated by the attention of the parents as the responsibility and figure for their children. Parents can shape the state of the child according to the methods and methods of parenting, educating, acting to argue, think, behave, and so on. ${ }^{2}$ According to Skinner, as quoted by Notoatmodjo, it is formulated that behavior is a person's response or reaction to external stimuli. ${ }^{22}$ Children's behavior in understanding and practicing the five daily prayer teachings and commendable values are the result of interaction behavior, parents on the one hand and children on the other, positive actions and attitudes shown by parents and children in family life. ${ }^{23}$ The interaction behavior of parents and children is an important factor in shaping the social and religious behavior of children in the family. ${ }^{24}$ There is a strong relationship between parents and children with each other, especially parent's influence, change, or improve children's behavior. ${ }^{25}$ Biological and social relationships between parents and children become the glue so that in their growth and development when children need high attention, parents play an important role in positioning themselves as caregivers, educators in parental interactions can create psychological conditions for

\footnotetext{
${ }^{19}$ Amalia, Akbar, and Syariful.

${ }^{20}$ Basidin Mizal, 'Pendidikan Dalam Keluarga', JIP-International Multidisciplinary Journal,
} II (2014), p. 158.

${ }^{21}$ Rini Lestari, 'Keluarga: Tempat Proses Belajar Perilaku Prososial', Prosiding Seminar Nasional Parenting, (2013), p. 63.

${ }^{22}$ Niken WN Palupi and Nurlia Ikaningtyas, 'Pengaruh Pembentukan Perilaku Caring Berbasis Stimulus - Organisme - Respon (Sor) Terhadap Perilaku Caring Mahasiswa Keperawatan', Jurnal Kesehatan, 5.2 (2018), h. 22. Hasan Mustafa, 'Perilaku Manusia dalam Perspektif Psikologi Sosial Hasan', Jurnal Administrasi Bisnis, 7 (2011), p. 154.

${ }^{23}$ Stephen P. Robbins, Essential of Organizational Behavior (edisi V), terj. Halida dan Dewi Sartika, Prinsip-prinsip Perilaku Organisasi (Jakarta: Erlangga, 2002), p. 2.

${ }^{24}$ Robert A, Baron, Social Psichology, terj. Ratna Djuita, Psikologi Sosial, Jilid I (Jakarta: Erlangga, 2003), h. 9, Hasan Mustafa, 'Perilaku Manusia dalam Perspektif Psikologi Sosial Hasan', Jurnal Administrasi Bisnis, 7 (2011), p. 153-154.

${ }^{25}$ Abu Ahmadi, Psikologi Sosial (T.tp: Riska Cipta, t.t.), p. 54. 
children to become children who have personal integrity. grow and are nurtured in a strong family.

\section{Islamic Perspective}

Islam as a religion has two main sources, namely al-Qur'an and hadith, both of which contain guidance and teachings, both relating to the relationship between humans and Allah the creator, humans and others in living life in the world. ${ }^{26}$ The Qur'an contains principle teachings consisting of faith, worship and morals. The verses that describe three human practices that govern the life of a believer are explicitly found in about five hundred verses. ${ }^{27}$ One of the cases mentioned explicitly by the Qur'an and even described in a pattern of childcare behavior is the family of Lukmaul Hakim. This shows that the family is a strategic institution for fostering families, especially children as part of the family, the hope for the future of the family and even society and the nation.

Hadith as the second source of law also explicitly views the importance of fostering children in a family." ${ }^{28}$ Hadiths are the words and deeds as well as the Prophet's recognition of the legality of the actions of a friend, apart from functioning as a second source of law, it is also a narrative that provides an explanation of the meaning contained in a verse. As Ali ibn Abi Talib RA said, teach yourself and your children goodness, (al-Hadith). ${ }^{29}$ This hadith emphasizes that religion and belief for every human being as well as the development of children's character processes through social interaction in their environment, namely the two parents as people who always accompany them in the household. According to Vigotsky, children learn through two stages, namely interaction with other people, parents, siblings, peers, teachers, and learn individually by integrating everything they learn from others in their cognitive structure. ${ }^{30}$ This shows that the formation of children's character, the family environment is very decisive in cultivating faith, understanding, practice and the norms and values of Islamic teachings.

\section{Methods}

This research was conducted using qualitative methods; primary data were collected through observation, interview and documentation. Observations focused on three schools as a collection of a heterogeneous study population. Interview was conducted using interview guidelines as a basis for formulating questions. The questions asked are transparent, covering three data fields, namely the internalization

\footnotetext{
${ }^{26}$ Muhammad Fu'ad Abd al-Bâqi, Saḥ̂hh Muslim (Juz IV, Indonesia: Maktbah Dahlan, t.th.), p. 2048.

${ }^{27}$ Rafat Y. Alwazna, 'Islamic Law: Its Sources, Interpretation and the Translation of It into Laws Written in English', International Journal for the Semiotics of Law, 29.2 (2016), p. 251.

${ }^{28}$ Irsyad Andriyanto, 'Strategi Pengelolaan Zakat Dalam Pengentasan Kemiskinan', Walisongo: Jurnal Penelitian Sosial Keagamaan, 19.1 (2011), p. 25.

${ }^{29}$ Ginanjar.

${ }^{30}$ Zubaedi, Strategi Taktis Pendidikan Karakter (Cet. I; Depok: PT Raja Grafindo Persada, 2017), p. 24.
} 
Family Resilience in Islamic Perspective

(A Case Study of Parent and Child Interaction

Abd Rahman $R$

Behavior in The District of Somba Opu Gowa)

of faith, teaching and practice of praying five times a day and morals by selecting 30 samples, each of which 18 students and 12 parents of students are incidentally sampled from three schools, namely SD Inpres Maccini Ayo represents Urban Village, Somba Opu district as well as District City, SD Inpres Samata represents the border area with Makassar City, and SD Inpres Bonto Ramba represents the outskirts of the City. The sample chosen consisted of boys and girls, both from grade VI elementary school students, and also parents as representatives of the family life of the Somba Opu District society. Secondary data obtained through literature, books and journals are used to support primary data obtained in the field. The data obtained is then processed, categorization is carried out based on the needs of the problem and the research objectives are analyzed qualitatively.

The research took place and was carried out in three elementary schools in the Somba Opu sub-district as a place for children's learning. At the same time, the child's parents make a shuttle from home to school and conversely. Children and children's parents as participants in this study were interviewed for their awareness and willingness. Questions were asked one by one openly in a situation when they were taking a break, outside of study hours and also the parents of the children who were waiting for the children to end up studying in class to be picked up home. The interviews were conducted in depth, as stated by Singarimbun and Efendi. ${ }^{3}$

\section{Results}

The interaction of parents and children is part of the dynamics in the family. In addition to being the husband of the wife, in terms of duty, status and role, the father is obliged to earn a living, also protects his family members. Parents of children are responsible for the family, for their children, pay attention to their children, not only to fulfill physical needs, but also spiritual needs, give attention and strengthen understanding and practice the norms and values of Islamic teachings, as seen from the results of the interview as follows:

"Our parents in the household teach about the faith that we must believe in Allah. Our parents teach that everything in the universe is the creation of Allah SWT., like the heavens and the earth and everything in them is Allah's creation".

What Annisa said is in line with what Auliyah Rosali and Muhammad Fauzan said:

"That our parents teach about faith through His creation, even parents teach the attributes of Allah, such as Allah is great, almighty and so on".

There was the recognition of the child's parents, Hamsina Daeng Nurung stated:

"...That my husband and I taught our children about believing in Allah SWT, not only believing in Allah, but also believing in the Day of Judgment".

Abd Rajab, the child's parent said:

\footnotetext{
${ }^{31}$ Masri Singarimbun dan Sofian Efendi (Editor), Metode Penelitian Survai (Cet. I; Jakarta: LP3ES, (1989), p. 192.
} 
“...... Besides I teach faith education to my children, as well as my wife, I even use free time, invite them to gather together, then I provide education and teaching about the pillars of faith, namely believing in Allah, His angels, His book, the Apostles, the hereafter, qadha and qadar".

Another case, the interaction behavior between parents and children related to the implementation and practice of worship is as follows:

Hamsinah Daeng Nurung and Sitti Wahyuni said:

"...that as a mother of children in our household, we often invite the children to pray in congregation."

"Awang said that as a parent I told the children to pray, and also taught the readings in prayer, but did not congregate in the family. We do this, taking turns with the wife so that they can carry out the movements and recitation properly"

Auliah Rosali said that:

"Our parents told him to pray every time the prayer arrived and this was often done with both parents, and if he didn't do it, the parents scolded him while advising him about the importance of prayer and the dangers of not doing it."

What Auliah Rosali said is in line with what was experienced by Asmaul Husna and Andi Annisa Aswari who said:

"...That our parents not only ordered prayers, but also gave teachings about the recitations in prayer and performed at certain times (spare). Our parents often invited us to sit down together and then gave instructions about the prayer procedures and the reading"

Arwin Aminuddin, a parent at SD Bonto-bontoa/Maccini Ayo said:

"...that as a parent of children, I did not order him, but $i$ invite the children to pray and we often do that with children, telling different to invite because children need a good example from parents".

Abd Rajab Daeng Rate said:

“... That his family teaches shame to his children related to politeness, good manners in association, not taking things if they don't belong (honesty), not being arrogant. All of which will damage the good name of the family, especially parents"

Aminah Daeng Te'ne, one parent said:

"...those children at home are taught to have shame. He emphasized two things, namely being ashamed of Allah if he did not observe the five daily prayers and instilling politeness in terms of respect for guests. He does not let his children walk around while people are entertaining guests",

Asmaul Husna said:

“...That our parents taught shame related to social relationships. Our parents taught shame through prohibitions in association with men”.

A mother (Ummiyati) of elementary school students in relation to the importance of cleanliness said: 
Family Resilience in Islamic Perspective

(A Case Study of Parent and Child Interaction

Behavior in The District of Somba Opu Gowa)

"As a parent of my child, I taught him to dispose of garbage in its place and forbid throwing garbage except in its place where to support this I prepared trash bins in the house and outside the house".

Another respondent who had an interview related to clean culture was Muhammad Daeng Pali, who said:

"...That as a parent, I teach cleanliness to children by preparing trash cans inside the house and outside the house"

Rayhan Pancahya WD, said:

"...that my parents taught about cleanliness by preparing trash bins in the house and outside the house, even I sometimes picks up trash scattered everywhere".

Amirullah Daeng Beta, parents in the family said:

"... That cleanliness is something that must be maintained through the provision of trash bins in the house and outside the house. Children are prohibited from littering in any place".

Arphiani Anugrah and Naila Salsabil said:

"Our parents taught us about cleanliness, further saying that we shouldn't throw garbage anywhere because it can pollute the environment. Our parents set up trash bins inside and outside the house"

Another case, the interaction behavior between parents and children related to the implementation and practice of worship is as follows:

\section{Parent and Child Interaction Behavior in the Family}

Table 1: Teaching and planting of faith

\begin{tabular}{|l|l|}
\hline CODE & Interaction Behavior \\
\hline Parents & $\begin{array}{l}\text { I teach shame to children in the family related to politeness, social } \\
\text { courtesy, not taking things if they don't belong (honesty), not } \\
\text { being arrogant. All of which will damage the good name of the } \\
\text { family, especially parents. }\end{array}$ \\
\hline Parents & $\begin{array}{l}\text { I teach children at home to have shyness. I emphasize two things, } \\
\text { namely being ashamed of Allah if you do not observe the five } \\
\text { daily prayers and also instilling politeness in terms of respect for } \\
\text { guests. She did not let her children walk around when people were } \\
\text { serving guests. }\end{array}$ \\
\hline Child & $\begin{array}{l}\text { Our parents teach shame about social relationships. Our parents } \\
\text { taught shame through the prohibition of associating with men. }\end{array}$ \\
\hline Child & $\begin{array}{l}\text { My parents teach about cleanliness by preparing trash bins inside } \\
\text { the house and outside the house, and I sometimes even pick up } \\
\text { trash that is scattered all over the place. }\end{array}$ \\
\hline
\end{tabular}


Table 2: Teaching and practicing the five daily prayers

\begin{tabular}{|l|l|}
\hline CODE & Interaction Behavior \\
\hline Parent & $\begin{array}{l}\text { As the mother of children in the household, I often invite my } \\
\text { children to pray in congregation }\end{array}$ \\
\hline Parent & $\begin{array}{l}\text { Awang said that I as a parent told the children to pray, and also } \\
\text { taught the readings in prayer, but did not congregate in the family. } \\
\text { We do this, taking turns with the wife so that they can carry out } \\
\text { the movements and recitation properly }\end{array}$ \\
\hline Child & $\begin{array}{l}\text { Our parents told him to pray every time the prayer arrived and this } \\
\text { was often done with both parents, and if he didn't do it his parents } \\
\text { scolded him while advising him about the importance of prayer } \\
\text { and the dangers of not doing it. }\end{array}$ \\
\hline $\begin{array}{l}\text { Our parents not only ordered prayers, but also gave teachings } \\
\text { about the recitations in prayer and performed at certain times } \\
\text { (spare). Our parents often invited us to sit down together and then } \\
\text { gave instructions about the prayer procedures and the reading }\end{array}$ \\
\hline $\begin{array}{l}\text { As a parent, I not only tell about prayers, but also I invite the } \\
\text { children to pray in congregation and we often do this with the } \\
\text { children, because telling is different from inviting because children } \\
\text { need good examples from parents }\end{array}$ \\
\hline \begin{tabular}{l} 
Source: Interview with parents and children \\
\hline
\end{tabular}
\end{tabular}

Tabel 3: Teaching and Practice of Noble Morals

\begin{tabular}{|l|l|}
\hline CODE & Interaction Behavior \\
\hline Parent & $\begin{array}{l}\text { I teach shame to children in the family related to politeness, social } \\
\text { courtesy, not taking things if they don't belong (honesty), not } \\
\text { being arrogant. All of which will damage the good name of the } \\
\text { family, especially parents }\end{array}$ \\
\hline Parent & $\begin{array}{l}\text { I teach children at home to have shyness. I emphasize two things, } \\
\text { namely being ashamed of Allah if you do not observe the five } \\
\text { daily prayers and also instilling politeness in terms of respect for } \\
\text { guests. She did not let her children walk around when people were } \\
\text { entertaining guests }\end{array}$ \\
\hline Child & $\begin{array}{l}\text { Our parents taught shyness about social relationships. Our parents } \\
\text { taught shame through the prohibition of associating with men }\end{array}$ \\
\hline Child & $\begin{array}{l}\text { Our parents taught about cleanliness, further saying that we should } \\
\text { not litter anywhere because it can pollute the environment. Our } \\
\text { parents set up trash bins inside and outside the house }\end{array}$ \\
\hline
\end{tabular}

Source: Interview with parents and children

Based on the results of interviews with parents and their children, as stated above, it shows that parents have carried out their roles and duties to teach and 
Family Resilience in Islamic Perspective

(A Case Study of Parent and Child Interaction

Abd Rahman $R$

Behavior in The District of Somba Opu Gowa)

implant the faith, pray five times a day and have noble morals. The roles and duties are carried out by the mothers because of the father's side with their activities in earning a living for household needs and needs. Parents have carried out their roles and duties as protectors and persons in charge of each household. There is an awareness of the child's parents to carry out their obligations as parents in the family related to planting norms and values of religious teachings, especially shame, politeness in association and cleanliness. The positive nature of the good values that are embedded and rooted in the child will become a family asset and an important part of family resilience in society.

\section{Factors Being Challenges and Constraints on Parent and Child Interaction Behavior Relation to Family Resilience}

The role of parents in the family are parenting and preserving the potential of the child, including cultivating and practicing norms and Islamic teaching values through habituation in order to form a child's character. It is very much determined by the process of interaction between parents and children as experiences through which they are experienced and potentially useful assets for children, especially in elementary school age. The integrity and personality of parents and their ability to understand Islamic teachings can be a determining factor, success or become an obstacle / hindrance in family development so that children do not or do not get enlightenment, transfer of teaching about Islamic teachings and practice well. Parents will experience challenges in interactions related to the cultivation of faith in children, as the respondent said, Ahmad Haikal said:

"...that in the case of direct cultivation of faith, orally it is not done by parents at home, parents do not teach how to believe in Allah"

Ahmad Rafel said:

"...That our parents did not introduce Allah SWT. through His creation, such as the moon, sun, stars and others.

Rindi Yani said:

"...That I received teaching about faith at school, not from my parents in the family.

"Our parents teach us about reading in prayer and order their children to carry out and if they don't do, they will be scolded, even get punished in the form of a blow to the back by the parents, even the head, but not to cause injury or pain, just what it is"

Nani Daeng Ngai, said:

"I order my children to pray, but rarely do it in congregation",32.

Table 4: Parents' Personality

\begin{tabular}{|l|l|}
\hline CODE & Interaction Behavior \\
\hline Child & $\begin{array}{l}\text { Whereas in the case of direct cultivation of faith, orally it is not } \\
\text { done by parents at home, parents do not teach how to believe in }\end{array}$ \\
\hline
\end{tabular}

${ }^{32}$ Parent of student, interview, September $20^{\text {th }}, 2017$. 


\begin{tabular}{|l|l|}
\hline & Allah. \\
\hline Child & $\begin{array}{l}\text { I received teaching about faith in school, not from my parents in the } \\
\text { family }\end{array}$ \\
\hline Child & $\begin{array}{l}\text { Our parents teach about reading in prayer and order their children to } \\
\text { carry out and if they don't do it, they will be scolded, even getting } \\
\text { punished in the form of a blow to the back by the parents, even the } \\
\text { head, but not causing injury or pain. }\end{array}$ \\
\hline Parent & I tell my children to pray, but rarely do it in congregation \\
\hline
\end{tabular}

Parents play very important role in the family and to fulfill the needs of all family members are required to also earn a living which can take up time, not only during the day, but also at night so that it is difficult to sit with their children, as said by the child's parents.:

"Amirullah Daeng Beta, that education for aqidah or faith in children is sometimes carried out due to busy factors in daily activities. He taught his children about believing in Allah SWT., although he did not specify the application and consequences for these teachings".

Meanwhile Saharia Daeng Ratu said:

"...I play a greater role than my husband in teaching faith education to children, because he is busy of seeking sustenance

Amirullah Daeng Beta in the interview said:

"...That I do education for aqidah or faith in children is only sometimes because of the busyness in my daily activities. I teach children about believing in Allah Almighty, although it does not specify the application and consequences of these teachings".

Muhammad Yunus Daeng Pali said:

"...That faith education for children is rarely carried out because of the busyness of their daily activities. Even though it can be covered by the wife or mother of the children who provide teaching and education for the faith, but it is not a routine".

Table 5: Factor of Business

\begin{tabular}{|l|l|}
\hline CODE & Interaction Behavior \\
\hline Parents & $\begin{array}{l}\text { I do education for aqidah or faith in children is only sometimes } \\
\text { because of the busyness in my daily activities. I teach children } \\
\text { about believing in Allah Almighty, although it does not specify the } \\
\text { application and consequences of these teachings }\end{array}$ \\
\hline Parent & $\begin{array}{l}\text { I play a greater role than my husband in teaching faith education to } \\
\text { children, because he is busy of seeking sustenance }\end{array}$ \\
\hline Parent & $\begin{array}{l}\text { I do education for aqidah or faith in children is only sometimes } \\
\text { because of the busyness in my daily activities. I teach children } \\
\text { about believing in Allah Almighty, although it does not specify the }\end{array}$ \\
\hline
\end{tabular}


Family Resilience in Islamic Perspective

(A Case Study of Parent and Child Interaction

Abd Rahman $R$

Behavior in The District of Somba Opu Gowa)

\begin{tabular}{|l|l|}
\hline & application and consequences of these teachings \\
\hline Parent & $\begin{array}{l}\text { I play a greater role than my husband in teaching faith education to } \\
\text { children, because he is busy of seeking sustenance }\end{array}$ \\
\hline
\end{tabular}

Source: Interview with parents and children

The frequency of interaction between parents and children based on Islam affects family resilience. Parents' busy lives limit their time to interact with their families, especially their children. Parents are busy with their careers or professions in earning a living, also children are busy in socializing, playing with their peers, causing attention to the care and education of children in the family limited, affection and direction are not felt by the children that in their age, they relatively need attention from parents. The lack of attention and lack of affection for children has a negative impact and even threatens the family's resilience

\section{Islamic-Based Effective Parent-Child Interaction Behavior to Build Family Resilience}

The behavior of parents and children in the interaction between the two parties based on Islam is meaningful towards the child and the association in his environment, this means that the intensity of the behavior interaction is needed for parenting, fostering and inculcating the values and norms of Islamic teachings through habituation to form good character cultivating monotheism from an early age, especially between the ages of seven and twelve has a positive impact on family resilience. In line with the following interview results:

Andi Annisa Aswari said:

“...That our parents often provide teachings about faith at home, although it is not in a structured and more detailed way about knowing Allah SWT."

Sasmila, one of the Maccini SD students, said:

"...Our parents teach us about the cultivation of faith, belief in Allah SWT, His angels, His holy book, Prophet Muhammad Saw. Furthermore, she said that the parents explained that the earth and its contents were the creation of Allah SWT. One day humans would be questioned in their graves"

Nurul Annisa said:

".....That my parents asked me to clean the house every day, like sweeping the room and the yard, I was taught not to throw garbage carelessly. Trash cans is put inside the house and outside the house"

Aminah Daeng Te'ne, parents of SDN Samata students said:

"...That I play the roles in providing teaching and faith education to children because my husband is busy with earning a living. I explained to my children that we must believe in Allah and do not do what Allah forbids, because it will a torment in the hereafter.

"My parents often taught in the household to respect each other in relationships, such as friends, neighbors, and other people, prohibited from criticizing or insulting fellow humans".

Hj. Andi Puncaniarti, the parents of the students said: 
"...that I often teach children about the shame associated with practicing the five daily prayers. He further said that Allah gave so much to us, and then we did not carry out His commands (prayer). So, we should be ashamed of Him. Likewise, he taught about the importance of covering one's genitals, something that is not visible to others".

Table 6: Intensity of Interaction and Internalization of Values and Norms

\begin{tabular}{|l|l|}
\hline CODE & Interaction Behaviour \\
\hline Child & $\begin{array}{l}\text { Our parents often provide teachings about faith at home, although } \\
\text { it is not in a structured and more detailed way about knowing } \\
\text { Allah SWT }\end{array}$ \\
\hline Parent & $\begin{array}{l}\text { I play the roles in providing teaching and faith education to } \\
\text { children because my husband is busy with earning a living. I } \\
\text { explained to my children that we must believe in Allah and do not } \\
\text { do what Allah forbids, because it will a torment in the hereafter }\end{array}$ \\
\hline Child & $\begin{array}{l}\text { Our parents teach us about the cultivation of faith, belief in Allah } \\
\text { SWT, His angels, His holy book, Prophet Muhammad Saw. } \\
\text { Furthermore, she said that the parents explained that the earth and } \\
\text { its contents were the creation of Allah SWT. One day humans } \\
\text { would be questioned in their graves }\end{array}$ \\
\hline Child & $\begin{array}{l}\text { My parents often taught in the household to respect each other in } \\
\text { relationships, such as friends, neighbors, and other people, } \\
\text { prohibited from criticizing or insulting fellow humans }\end{array}$ \\
\hline Child & $\begin{array}{l}\text { My parents often taught in the household to respect each other in } \\
\text { relationships, such as friends, neighbors, other people, prohibited } \\
\text { from criticizing or berating fellow humans }\end{array}$ \\
\hline Parent & $\begin{array}{l}\text { I often teach children about the shame associated with practicing } \\
\text { the five daily prayers. He further said that Allah gave so much to } \\
\text { us, and then we did not carry out His commands (prayer). So, we } \\
\text { should be ashamed of Him. Likewise, he taught about the } \\
\text { importance of covering one's genitals, something that is not visible } \\
\text { to others". }\end{array}$ \\
\hline
\end{tabular}

Source: Interview with parents and children

Parents' advice to their children as an internalization that will become thick in a memory for the children, which if done repeatedly by the parents of the children forms character, politeness, tolerance and others in society life. Intensive cultivation of faith in children is urgent in the development of their lives, starting from an early age. The faith is the moral foundation in religious life for humans, especially for children who are growing. Therefore, the role of the people around him, especially the parents (father and mother) in the household as the first teachers for their children is very important. Thus parents have a great influence on their children of their generation, both character and belief. 
Family Resilience in Islamic Perspective

(A Case Study of Parent and Child Interaction

Abd Rahman $R$

Behavior in The District of Somba Opu Gowa)

\section{E. Discussions}

This study shows that family resilience in the interaction behavior of parents as the person responsible for the development and growth of children, the role and duties of parents as teachers, the first educators have walked in the family. ${ }^{33}$. he roles and duties of parents face problems with the complexities of modern life styles faced by parents and children ${ }^{34}$. Parents, as the responsibility for meeting the demands of the material family needs, keep them busy in earning a living so that they have relatively little time to sit together in the family, and they are also tired when they come home from work, at the same time the children need attention from their parents ${ }^{35}$. There are obstacles and challenges in the care and education of the household by parents, not only busyness, but also the competence of parents in providing teaching about the faith and understanding of the teachings of the faith and prayer procedures are relatively lacking, expect teaching to be given at school ${ }^{36}$.

The pattern of interaction between parents and children that is not intense and the ability of personal competence is less and the condition of parents who spend a lot of time in routine activities to earn a living as the person in charge of the care and fostering of children in the family reflects the educational conditions of children in the family that carry risks to resilience of family ${ }^{37}$. The competence of parents is low or lacking in their role as caregivers and educators are regarding the growth and development of children in understanding and practicing Islamic teachings and values properly, forming children who do not have a strong understanding and practice of the teachings of the creed and the five daily prayers from age early ${ }^{38}$. This pattern of interaction behavior can be a cause that produces juvenile delinquency, a threat to family resilience, and even community life in the future ${ }^{39}$. Meanwhile, the flow of Western culture with a hedonistic life and a materialistic lifestyle has high strength and attractiveness, which can lead children to become a generation that does not have personal integrity and a strong sense of religiosity.

Research on family resilience has shown various dimensions, not only social, economic, but also gender and health violence. However, the existing study does not show an analysis that looks at the dimensions of the behavior patterns of the interaction between parents and children towards fostering children in the family. The

33 Basidin Mizal, 'Pendidikan Dalam Keluarga', JIP-International Multidisciplinary Journal, II (2014), p. 167.

34 Hendarti Purnomo, 'Peran Orang Tua Dalam Optimalisasi Tumbuh Kembang Anak Untuk Membangun Karakter Anak Usia Dini', in Prosiding Seminar Nasional Parenting, (2013), p. 35.

35 Hasan Baharun, 'Pendidikan Anak Dalam Keluarga; Telaah Epistemologis', Jurnal Pedidikan, 3.2 (2016), p. 103.

36Samhi Muawan Djamal, 'Penerapan Nilai-Nilai Ajaran Islam Dalam Kehidupan Masyarakat Di p’164.

37 Purnomo, p. 35.

38 Sofinas Z Asaari dkk, 'Telaah Kebijakan Interaksi Komunikasi Efektif Antar Orang Tua Dan Anggota Keluarga Terhadap Ketahanan Keluarga di Provinsi DKI Jakarta’, 23.2 (2016), p. 40.

39 Mizal, h. 167 . 
results show that the difficulty of interacting with parents and children in the family is a problem in parenting, fostering children who need adequate attention ${ }^{40}$. Parents do not allocate sufficient time to transform knowledge and understanding of the teachings of faith, prayer and commendable moral values ${ }^{41}$. At the same time, the duties and roles of parents in the transformation of knowledge regarding the teachings and understanding of the teachings of faith and prayer are borne by schools. The disparity in the roles and duties of parents in coaching children in the family imposes entirely on the school ${ }^{42}$. The results of this study show the threat of family resilience in the future, so that it requires a shared responsibility, family and school, as well as the surrounding community, especially family institutions as the first environment in carrying out parent-child interactions for children's growth and development. ${ }^{43}$. The interaction behavior of parents and children should be allocated time for the transformation of faith knowledge as a foundation in religion ${ }^{44}$, as well as habituation in practicing the teachings of the five daily prayers and commendable values by providing examples for children in the family.

\section{F. Conclusion}

The roles and duties of parents who are considered to be responsible are not only fulfilling material needs, but also needs that are emotional and spiritual intelligence. The responsibility of parents as caregivers and first educators for their children in the family is the interaction behavior between the two parties which leads to difficulties in teaching and understanding the teachings of the faith and the practice of the five daily prayers and habituation to the practice of moral values, namely Parents' competence is inadequate for the cultivation of faith and teaching procedures for the five daily prayers, and being busy is a factor in allocating time when it is difficult to sit with their children in the household. The ability and competence factors of parents limit the transformation and teaching of their children, as well as the busyness of parents in their routine activities to make a living from morning to evening, even at night when they arrive home.

Family resilience in this study allows finding space to explain how the family is a strategic base of education. Parents are obliged to carry out their roles and duties in the family as first teachers by intensifying interaction and allocating adequate time for teaching and understanding the cultivation of faith and practice of the five daily prayers as well as noble morals for children at an early age. Parents as the first teachers for their children have a strong relationship to nurture their children in the household for the process of growth and development so that later they have a strong sense of religiosity and personality. The family environment as the smallest institution

40 Ulfiah, 'Prostitusi Remaja Putri dan Ketahanan Keluarga Di Cianjur Jawa Barat', 2017, p.

113.

41 Ulfiah, p. 113

42 Intan Kusumawati, 'Landasan Filosofis Pengembangan Karakter Dalam Pembentukan Karakter', Academy of Education Journal, 7.1 (2016), p. 1.

43 Mizal, p. 156.

44 Dewi Nur Susi Atina Tri Rokhmatin, 'Analysis Of Educational Val', 1.1 (2016), p. 5.

Jurnal Adabiyah Vol. 20 Nomor 2/2020 
Family Resilience in Islamic Perspective

(A Case Study of Parent and Child Interaction

Abd Rahman $R$

Behavior in The District of Somba Opu Gowa)

in a society that is built on a strong religious life, giving birth to a family resilience, having a positive impact on the life of the wider community, even the state and nation.

This study is limited to the interaction behavior of parents with their roles and duties towards teaching and fostering children in the family in relation to family resilience. The roles and duties of parents are very central to the teaching and guidance of children in the family. Internalization of the faith and the teachings of the five daily prayers and habituation of noble character in the family are very possible for parents to form family resilience. In line with that, further research is needed that looks at the method of interaction between parents and children that are contextual, in accordance with the times in the form of interactions via the WhatsApp group (GWA) so that they can find comprehensive problem solutions.

\section{BIBLIOGRAPHY}

Alwazna, Rafat Y., 'Islamic Law: Its Sources, Interpretation and the Translation of It into Laws Written in English', International Journal for the Semiotics of Law, 29.2. 2016.

Amalia, Rizqi Maulida, Muhammad Yudi Ali Akbar, and Syariful Syariful, 'Ketahanan Keluarga Dan Kontribusinya Bagi Penanggulangan Faktor Terjadinya Perceraian', Jurnal Al-Azhar Indonesia Seri Humaniora, 4.2. 2018.

Andriyanto, Irsyad, 'Strategi Pengelolaan Zakat dalam Pengentasan Kemiskinan', Walisongo: Jurnal Penelitian Sosial Keagamaan, 19.1. 2011.

Atina Tri Rokhmatin, Dewi Nur Susi, 'Analysis of Educational Val', 1.1. 2016.

Baharun, Hasan, 'Pendidikan Anak Dalam Keluarga; Telaah Epistemologis', Jurnal Pedidikan, 3.2. 2016.

Djamal, Samhi Muawan, 'Penerapan Nilai-Nilai Ajaran Islam Dalam Kehidupan Masyarakat Di Desa Garuntungan Kecamatan Kindang Kabupaten Bulukumba', Jurnal Adabiyah, 17.2. 2017.

Fitriana, Yuni, Kurniasari Pratiwi, and Andina Vita Sutanto, 'Faktor-Faktor Yang Berhubungan Dengan Perilaku Orang Tua Dalam Melakukan Kekerasan Verbal Terhadap Anak Usia Pra-Sekolah', Jurnal Psikologi Undip, 14.1. 2015.

Ginanjar, M. Hidayat, 'Keseimbangan Peran Orang Tua Dalam Pembentukan Karakter Anak', Edukasi Islami: Jurnal Pendidikan Islam, 2.03. 2017. 
Hasan Mustafa, 'Perilaku Manusia Dalam Perspektif Psikologi Sosial Hasan', Jurnal Administrasi Bisnis, 7. 2011.

Herdiana, Ike, Dr. Suryanto, and Seger Handoyo, 'Family Resilience: A Conceptual Review', 2018.

Herlina, 'Gender Harmony Dalam Pembangunan Ketahanan Keluarga', Jurnal AlHimayah, 2.1. 2018.

Ikhwan, Afiful, Oktio Frenki Biantoro, and Ali Rohmad, 'The Role of the Family in Internalizing Islamic Values', Dinamika Ilmu, 19.2. 2019.

Ismail, Ismail, 'Optimalisasi Pelaksanaan Program Kelompok Usaha Mandiri Masyarakat - Program Ibu Mandiri dalam Meningkatkan Pendapatan Rumah Tangga dan Implikasinya terhadap Ketahanan Ekonomi Rumah Tangga (Studi di PKPU Yogyakarta)', Jurnal Ketahanan Nasional, 21.3. 2015.

Kusumawati, Intan, 'Landasan Filosofis Pengembangan Karakter dalam Pembentukan Karakter', Academy of Education Journal, 7.1. 2016.

Lestari, Rini, 'Keluarga: Tempat Proses Belajar Perilaku Prososial', Prosiding Seminar Nasional Parenting 2013, 2013.

Limilia, Putri, and Benazir Bona Pratamawaty, 'Pelatihan Literasi Media Digital Sebagai Penanggulangan Dampak Negatif Internet Pada Ketahanan Keluarga', Jurnal Abdi Moestopo, 01.01. 2017.

Mada, Universitas Gadjah, 'Pedoman Kerjasama Institusional', November, 2011.

Makmudi, Makmudi, Ahmad Tafsir, Ending Bahruddin, and Akhmad Alim, 'Urgensi Pendidikan Akhlak dalam Pandangan Imam Ibnu Qayyim Al-Jauziyyah', Ta'dibuna: Jurnal Pendidikan Islam, 8.1. 2019.

Mizal, Basidin, 'Pendidikan Dalam Keluarga', JIP-International Multidisciplinary Journal, II. 2014.

Palupi, Niken WN, and Nurlia Ikaningtyas, 'Pengaruh Pembentukan Perilaku Caring Berbasis Stimulus - Organisme - Respon (Sor) Terhadap Perilaku Caring Mahasiswa Keperawatan', Jurnal Kesehatan, 5.2. 2018.

Puniman, Ach., and Kadarisman Kadarisman, 'Pendidikan Anak dalam Perspektif Islam', Alpen: Jurnal Pendidikan Dasar, 2018.

Purnomo, Hendarti, 'Peran Orang Tua Dalam Optimalisasi Tumbuh Kembang Anak Untuk Membangun Karakter Anak Usia Dini', in Prosiding Seminar Nasional Parenting, 2013.

Siahaan, Rondang, 'Ketahanan Sosial Keluarga: Perspektif Pekerjaan Sosial (Family Resiliency : Sosial Work Perspective)', Informasi, 17.02. 2012. 
Family Resilience in Islamic Perspective

(A Case Study of Parent and Child Interaction

Behavior in The District of Somba Opu Gowa)

Sofinas Z Asaari dkk, 'Telaah Kebijakan Interaksi Komunikasi Efektif Antar Orang Tua dan Anggota Keluarga terhadap Ketahanan Keluarga Di Provinsi DKI Jakarta', 23.2. 2016.

Suratno, 'Pengaruh Lingkungan Keluarga dan Lingkungan Pergaulan Terhadap Prestasi Belajar Ekonomi Siswa', Pengaruh Lingkungan Keluarga Dan Lingkungan Pergaulan Terhadap Prestasi Belajar Ekonomi Siswa, 9.1. 2014.

Taubah, Mufatihatut, 'Pendidikan Anak dalam Keluarga Perspektif Islam Mufatihatut Taubah (Dosen Stain Kudus Prodi Pai)', JUrnal Pendidikan Agama Islam, 3.1. 2016.

Ulfiah, 'Prostitusi Remaja Putri Dan Ketahanan Keluarga Di Cianjur Jawa Barat', 2017. 


\section{Guidelines}

\section{Submission of Article}

urnal Adabiyah welcomes the articles submission with the main themes on Humanities and Islamic Studies with the emphasis on interdisciplinary and intertextuality approach. Adabiyah is thematicly published twice in a year. ie the theme of the humanities in June and the Islamic Study in December.

Themes related to Islamic Studies are textual studies, scriptural traditions, Islamic law, and theology; and those related to Humanities are language, literature, history, and culture. This scholarly journal Guarantees that the editor decision based on the peer review results will not exceed 30 days from the paper submission date.

Authors are invited to read our archives; to find the relevant topics for the journal, and to submit complete unpublished scientific researches, which are not under review in any other conferences or academic journal.

\section{PUBLICATION ETHIC}

Publication Ethic and Malpractice Statement

Jurnal Adabiyah is a peer-reviewed journal, published twice a year by the Faculty of Adab and Humaniora, Alauddin State Islamic University of Makassar Indonesia. It is available online as open access sources as well as in print. This statement clarifies ethical behaviour of all parties involved in the act of publishing an article in this journal, including the author, the editor-in-chief, the Editorial Board, the reviewers, and the publisher. This statement is based on COPE's Best Practice Guidelines for Journal Editors.

Ethical Guideline for Journal Publication

The publication of an article in Jurnal Adabiyah, is an essential building block in the development of a coherent and respected network of knowledge. It is a direct reflection of the quality of the work of the authors and the institutions that support them. Peer-reviewed articles support and embody the scientific methods. It is therefore important to agree upon standards of expected ethical behavior for all parties involved in the act of publishing: the author, the editor, the reviewer, the publisher, and the society. As the publisher of Jurnal Adabiyah, the Faculty of Adab and Humaniora takes its duties of guardianship over all stages of publishing seriously and it recognizes its ethical and other responsibilities. The Faculty of Adab and Humaniora committed to ensuring that advertising, reprint or other commercial revenue has no impact or influence on editorial decisions.

\section{Publication Decisions}

The editors of Jurnal Adabiyah is responsible for deciding which articles submitted to the journal should be published. The validation of the work in question and its importance to researchers and readers must always drive such decisions. The editors may be guided by the policies of the journal's editorial board and constrained by such legal requirements as shall then be in force regarding libel, copyright infringement, and plagiarism. The editors may confer with other editors or reviewers in making their decisions.

\section{Plagiarism Screening}

It is basically author's duty to only submit a manuscript that is free from plagiarism and academically malpractices. The editor, however, will check all submitted papers through Turnitin.

\section{Fair Play}

An editor at any time evaluates manuscripts for their intellectual content without regard to race, gender, sexual orientation, religious belief, ethnic origin, citizenship, or political philosophy of the authors. 


\section{Confidentiality}

The editors and any editorial staff must not disclose any information about a submitted manuscript to anyone other than the corresponding author, reviewers, potential reviewers, other editorial advisers, and the publisher, as appropriate.

\section{Disclosure and Conflicts of Interest}

Unpublished materials disclosed in a submitted manuscript must not be used in editors' own research without the express written consent of the author.

\section{DUTIES OF AUTHORS}

\section{Reporting Standards}

Authors of reports of original research should present an accurate account of the work performed as well as an objective discussion of its significance. Underlying data should be represented accurately in the paper. A paper should contain sufficient detail and references to permit others to replicate the work. Fraudulent or knowingly inaccurate statements constitute unethical behaviour and are unacceptable.

\section{Originality and Plagiarism}

The authors should ensure that they have written entirely original works, and if the authors have used the work and/or words of others that this has been appropriately cited or quoted.

\section{Multiple, Redundant, or Concurrent Publication}

An author should not in general publish manuscripts describing essentially the same research in more than one journal or primary publication. Submitting the same manuscript to more than one journal concurrently constitutes unethical publishing behaviour and is unacceptable.

\section{Acknowledgement of Sources}

Proper acknowledgment of the work of others must always be given. Authors should cite publications that have been influential in determining the nature of the reported work.

\section{Authorship of the Paper}

Authorship should be limited to those who have made a significant contribution to the conception, design, execution, or interpretation of the reported research. All those who have made significant contributions should be listed as co-authors. Where there are others who have participated in certain substantive aspects of the research project, they should be acknowledged or listed as contributors. The corresponding author should ensure that all appropriate co-authors and no inappropriate co-authors are included on the paper, and that all co-authors have seen and approved the final version of the paper and have agreed to its submission for publication.

\section{Disclosure and Conflicts of Interest}

All authors should disclose in their manuscript any financial or other substantive conflict of interest that might be construed to influence the results or interpretation of their manuscript. All sources of financial support for the project should be disclosed.

\section{Fundamental errors in Published Works}

When an author discovers a significant error or inaccuracy in his/her own published work, it is the author's obligation to promptly notify the journal editor or publisher and cooperate with the editor to retract or correct the paper.

\section{PLAGIARISMIE}

It is basically author's duty to only submit a manuscript that is free from plagiarism and academically malpractices. The editor, however, will check all submitted papers through Turnitin. 


\section{AUTHOR GUIDELINES}

\section{Guidelines for online submission:}

1. Author should first register as Author to the website of Jurnal Adabiyah. Click the menu "register" to register as an author.

2. Once after the author is registered, please login to the website of Jurnal Adabiyah and submit the article through online submission (with the stat us of active submissions).

3. The article should follow the standard template of Jurnal Adabiyah provided in the website.

4. The citation and bibliography should follow the Turabian citation style.

5. Author is restricted not to send his/her article to another journal before having confirmation from the editorial team (approximately 4 weeks right after the article submitted).

6. Author should follow editorial decisions and recommendations related to the article completion. All reviews and assessements will be informed through online submission.

Article submitted to Jurnal Adabiyah editorial board must follow these guidelines:

1. Article should be based on the scientific research in the field humanities and Islamic studies;

2. Article must be an original work and has not been previously published;

3. Article should be written in Arabic or English languages;

4. Article must be typed in one-half spaced on A4-paper size;

5. Article's length is about $6,000-10,000$ words;

6. All submission must include a 150-250 word abstract;

7. Abstract should be written in 3 languages; Arabic, English, and Bahasa;

8. Full name(s) of the author(s) must be stated, along with his/her/their institution and complete address;

9. All submission should be in OpenOffice, Microsoft Word, RTF, or WordPerfect document file format;

10. Bibliographical reference must be noted in footnote and bibliography according to Jurnal Adabiyah style. In addition, it is suggested for author(s) to use reference manager tools such

\section{as MENDELEY or 7 otero}

When a source is cited for the first time, full information is provided: full name(s) of author(s), title of the source in italic, place of publication, publishing company, date of publication, and the precise page that is cited. For the following citations of the same source, list the author's last name, two or three words of the title, and the specific page number(s). The word ibid., op.cit., and loc.cit. are may not be used any more.

\section{Example in footnotes:}

${ }^{1}$ Mircea Eliade (ed.), The Encyclopedia of Religion, vol. 8 (New York: Simon and Schuster, 1995), h. 18.

${ }^{2}$ Norman Daniel, Islam and the West (Oxford: One World Publications, 1991), h. 190.

${ }^{3}$ Syeikh Ja'far Subhāni, Mafăhim Al-Qur'ān (Beirut: Mu'assasah Al-Tarīkh Al-'Arabī, 2010)., Juz 5, h. 231. 
${ }^{4}$ Syeikh Ja'far Subhānī, Mafāhim Al-Qur'ān, h. 8-9.

\section{Example in bibliography:}

Subhānī, Syeikh Ja'far. Mafăhim Al-Qur'ān. Beirut: Mu'assasah Al-Tarīkh Al-’Arabī, 2010.

Eliade, Mircea (ed.). The Encyclopedia of Religion, vol. 8. New York: Simon and Schuster, 1995.

Daniel, Norman. Islam and the West. Oxford: One World Publications, 1991.

Shihab, Muhammad Quraish. Sunnah-Syiah Bergandengan Tangan: Mungkinkah? Kajian Atas Konsep Ajaran Dan Pemikiran. Cet. III. Jakarta: Lentera Hati, 2007.

\section{Detail informations of the footnotes:}

1. Holy book

Al-Qur'ân, Al-Baqarah/2: 185.

Perjanjian Baru, Mrk. 2: 18.

2. Qur'anic translation

${ }^{1}$ Departemen Agama RI, al-Qur'an dan Terjemahannya (Jakarta: Darus Sunnah, 2005), h. 55.

3. Book

${ }^{1}$ Muḥammad 'Ajjaj al-Khațib, Ușl al-Hadith: 'Ulumuh wa Mușțalaḥ uh (Beirut: Dâr al-Fikr, 1989), h. 57.

4. Translation Books

${ }^{1}$ Toshihiko Izutsu, Relasi Tuhan dan Manusia: Pendekatan Semantik terhadap al-Qur'an, terj. Agus Fahri Husein dkk (Yogyakarta: Tiara Wacana, 2003), h. 14.

5. Voluminous book

${ }^{1}$ Muḥammad al-Ṭâhir b. 'Ashur, al-Tahrīir wa al-Tanwīr, Vol. 25 (Tunisia: Dâr al-Suhûn, 2009), h. 76.

${ }^{1}$ Muḥammad b. Ismā‘īl al-Bukharī, al-Jami‘ al-Ṣaḥịh, Vol. 2 (Beirut: Dar al-Kutub al-‘Ilmı́yah, 1999), h. 77.

6. Article in book

${ }^{1}$ Sahiron Syamsuddin, "Metode Intratekstualitas Muhammad Shahrur dalam Penafsiran al-Qur'an" dalam Abdul Mustaqim dan Sahiron Syamsuddin (eds.), Studi al-Qur'an Kontemporer: Wacana Baru Berbagai Metodologi Tafsir (Yogyakarta: Tiara Wacana, 2002), h. 139.

7. Article in encyclopaedia

${ }^{1}$ M. Th. Houtsma, "Kufr" dalam A. J. Wensinck, at al. (ed.), First Encyclopaedia of Islam, Vol. 6 (Leiden: E.J. Brill, 1987), h. 244.

8. Article in journal

${ }^{1}$ Muhammad Adlin Sila, "The Festivity of Maulid Nabi in Cikoang, South Sulawesi: Between Remembering and Exaggerating the Spirit of Prophet", Studia Islamika 8, no. 3 (2001): h. 9.

9. Article in mass media

${ }^{1}$ Masdar F. Mas'udi, "Hubungan Agama dan Negara”, Kompas, 7 Agustus 2002. 
10. Article in Internet

${ }^{1}$ Muhammad Shahrūr, "Reading the Religious Teks: a New Approach" dalam http://www.shahrour.org/25 Februari 2010/diakses 5 Juni 2010.

11. Thesis or dissertation

${ }^{1}$ Syahruddin Usman, "KinerjaGuru Penddikan Agama Islam pada SMAN dan SMKN Kota Makassar”, Disertasi (Makassar: PPs UIN Alauddin, 2010), h. 200.

\section{COPYRIGHT NOTICE}

Authors who publish with this journal agree to the following terms:

1) Authors retain copyright and grant the journal right of first publication with the work simultaneously licensed under a Creative Commons Attribution License that allows others to share the work with an acknowledgement of the work's authorship and initial publication in this journal.

2) Authors are able to enter into separate, additional contractual arrangements for the non-exclusive distribution of the journal's published version of the work (e.g., post it to an institutional repository or publish it in a book), with an acknowledgement of its initial publication in this journal.

3)Authors are permitted and encouraged to post their work online (e.g., in institutional repositories or on their website) prior to and during the submission process, as it can lead to productive exchanges, as well as earlier and greater citation of published work (See The Effect of Open Access). 